\title{
Local Wisdom and Character Education
} in Youth Organizations

\section{A Case Study of South Sulawesi Province, Indonesia}

\author{
Mujib Hasib \\ Universitas Muhammadiyah Makassar, \\ Indonesia \\ mujib_hasib@yahoo.com \\ Zulfan Nahruddin \\ Universitas Muhammadiyah Makassar, \\ Indonesia \\ Muchlas M Tahir \\ Universitas Muhammadiyah Makassar, \\ Indonesia
}

\author{
Handam \\ Universitas Muhammadiyah Makassar, \\ Indonesia \\ Muh. Firyal Akbar \\ Universitas Muhammadiyah Gorontalo, \\ Indonesia \\ Wahyu Nurdiansyah \\ Universitas Hasanuddin, Indonesia \\ wnurdiansyah90@yahoo.co.id
}

\begin{abstract}
This study aimed to figure out how the characteristics of youth organization in South Sulawesi. The developing local wisdom in youth organization in South Sulawesi. Developing process of local wisdom becoming character education in South Sulawesi. Research method employed is qualitative approach with descriptive research type, then the data collection acquired through observation and interview. The data analyzing process including data reduction, data presentation, and conclusion making. The result showed that the existence of character value implantation in youth could possibly done through youth organization activity although possessing various characteristics but the culture value absorbing could happen inside of it. What supposed to be positive could be negative if their dignity violated. Furthermore, the culture in youth organization in South Sulawesi understood that organization brings a lot influences to character and self physicology. Moreover, the value of the cultures can evolve to form characteristics that can conjure characters with characteristics of respect and respect for others.
\end{abstract}

Keywords: local wisdom; character education; youth

\section{INTRODUCTION}

Character education today has become an important issue in education. The decline of the morality of society has long been happening, along with the times and technologies that accelerate the process of transferring cultural values. This leads to a discrepancy between the character of the next generation with the sociocultural value of society. The shift in value is increasing with the influence of foreign cultures that dominate through various media. As a result, the character that became the identity of the nation began to be eliminated. However, there is still the identity of the surviving group. This is because of the superior social value and not displaced by the time and the development of the era of local wisdom.

Local wisdom (local genius) is a truth that has become tradition or steady in an area. Local wisdom is a fusion of the sacred values of God's word and various values. Local wisdom is formed as a cultural superiority of local communities and geographical conditions in a broad sense. Local wisdom is a cultural product of the past that should be constantly used as a grip of life. Although the valued locally but the value contained therein is considered very universal [1].

Traditional wisdom is all forms of knowledge, belief, understanding or insight and customs or ethics that guide human behavior in life in an ecological community. So, this local wisdom is not only about the knowledge and

Corresponding author: Mujib Hasib 
understanding of indigenous peoples about human beings and how good relationships between people, but also about knowledge, understanding and customs about humans, nature and how the relation among all the inhabitants of this ecological community must be built. All of this traditional wisdom is experienced, practiced, taught and passed from one generation to another that simultaneously shapes the pattern of everyday human behavior, both to fellow human beings and to nature and the invisibility [2]. Local wisdom is also defined as the process by which knowledge is generated, stored, applied, and inherited "[3].

In [4] explains that: according to cultural perspective, local wisdom is various values created, developed and maintained by society that becomes their life guidance. Including various mechanisms and ways of behaving and acting which is realized as a social order.

In summary, local wisdom can be summed up as an important standard in living social life in a community group that becomes the identity of the community itself. One example of local wisdom that exists in sulawesi is siri 'na pacce. Siri' is a shame that decomposes in the dimensions of human dignity and dignity, siri' is something' taboo 'for Bugis-Makassar people in interacting with others. Meanwhile, pacce teaches the sense of solidarity and selfless social care and this group is one of the concepts that make the Bugis-Makassar tribe able to survive and respected monitored, pacce is the nature of compassion and feelings bear the burden and suffering of others, if the term in language of Indonesia "Mildly cared the same weight carrying the same weight".

The most influential thing in character building is the environment. At least there are 3 types of environment including family environment, school, and society.

One of the important fighting media in character building is the youth organization that plays an important role in the society. Of course, the implementation of local wisdom will be more effective through youth agencies as a forum that preserves the identity of the nation. According to Suyanto in [5] Character education is character education plus, which involves aspects of knowledge (cognitive), feeling, and action.

One of the researches related to local wisdom as a container of character education [6] found that the existing culture in an effective area used for the planting and development of character education in elementary school children. Then the research [7] shows local traditions or culture in the internalization of character education through school programs such as local content. Traditions or local cultures include such habits as: a) local language lessons, local narratives, and local social cultures.

The fundamental thing that distinguishes from previous research is the viewpoint of researchers who see character education that is embedded in local wisdom existing in youth organizations that then form the organizational culture is an interesting side to be traced, considering the participation of youth in the organization is a container of informal education.

\section{RESEARCH METHOD}

This research uses qualitative research type. Qualitative research is a method of exploring and understanding the meaning that by some individuals or groups of people ascribed to social or humanitarian problems [8]. Then according to [9] qualitative research is a study that intends to understand the phenomenon of what is experienced by research subjects, such as behavior, perception, motivation, action, etc .., holistically (intact) and by way of description in the form of words and languages in a specific, natural context by utilizing natural methods.

The type used in this research is descriptive research type. Descriptive research is limited to an attempt to express a problem or situation or event as it is so as to reveal facts and provide an objective picture of the true state of the object under study. Objects studied is the local wisdom that used as a container in building a characteristic education in youth organizations in southern Sulawesi. Data collection techniques used in this study are: observation, i.e. direct observation in the field in accordance with the object under study; Interviews, namely direct interviews to informants i.e. youth and youth organization board.

Data analysis techniques in this study using Miles and Huberman model that suggests that the activities in qualitative data analysis done interactively and continuously and until completed, so that the data is saturated. Activities in data analysis, namely data reduction, display data, and conclusion drawing / verification. [10]. Basically, this research answered following questions, namely:

1. How Characteristic of Youth Organization in South Sulawesi?

2. How is local Wisdom growing in youth organizations in South Sulawesi?

3. The process of development of local wisdom into character education in South Sulawesi? 


\section{RESULT AND DISCUSSION}

\section{A. Characteristics of Youth Organizations in South Sulawesi}

One organization that can be used as a place to instill the values of character in youth is through youth organization of youth. Karang Taruna is a forum for the development of nonpartisan youth generation, which grows on the basis of awareness and sense of social responsibility from, by and for the community, especially the younger generation in the village or similar social community, which is mainly engaged in social welfare. As a youth social organization, Karang Taruna is a forum for fostering and developing as well as empowering the young generation in an effort to develop Social Welfare Services activities and productive economic efforts by utilizing all available potentials in the environment both human and natural resources that already exist. In addition, youth organization is a youth organization whose membership is not based on a particular background, which means that membership of youth is not based on a person's education level or based on the educational strata they have.

The interview result shows that in general the youths have high enthusiasm to get involved in youth activities. The cultivation of character values in youth can be implemented through youth community youth activities. In addition, youth cadets are a place for youth to channel their potentials. Each member of karang taruna must have a work program implemented, where in each work program there are values that should exist in every youth. For example, the planting of character value is when in the implementation of the work program requires awareness to take full responsibility for every activity performed properly. In addition, there are also other character values that can encourage a young man so that later can become a better person with a better person. Therefore, the planting of characters in youth can be started from the participation of youth in the organization of youth.

Then there are religious organizations such as Muhammadiyah, an autonomous organization within Muhammadiyah which is an Islamic propagation movement, Islamic, and derived from the holy Qur'an (Islam holy book). The organization was founded with the intent and purpose to collect, foster, and mobilize the potential of Islamic Youth and improve its role as a cadre to achieve Muhammadiyah's goals, is a youth organization born with the same spirit with the establishment of Muhammadiyah, the spirit to build a strong generation for Future.
The results of the interviews indicate that the activities in the religious field, especially youth Muhammdiyah provide positive implications for youth empowerment of youths to have wide opportunities to develop their skills, among others, to be a good planner in every activity. Youth can take part in facilitating the event procession so as to gain an opportunity to gain experience that helps in character development and self-maturity.

There are also organizations like other youths such as KNPI (Youth National Committee of Indonesia), this organization was born through the Indonesian Youth Declaration on the same day with the intention of growing, improving and developing awareness as an independent and sovereign nation based on Pancasila and the 1945 Constitution. KNPI is different from the form of organization Youths previously known, such as the federated Youth Front whose members consist of youth mass organizations, the Committee does not recognize membership of mass organizations, therefore the Committee is not a federation. With the courage to display the exponents of youth figures sourced from all the youth mass organizations that exist at the national level as people who are trusted as a leader of this KNPI, it is not excessive if KNPI will have resonance in the community, especially among youth. Based on the interviews it is known that KNPI's position is independent and re-positioned the youth as a critical partner of the government in development.

\section{B. Improved Local Wisdom in Youth Organizations}

In South Sulawesi, the siri'-masiri (being ashamed) context defines siri 'as a spiritual driver that guides South Sulawesi people's behavior in dealing with and solving various problems. In the lontara (south Sulawesi letter) manuscript 'depicting siri' includes not only the effect but also the self-reflection. People feel ashamed (siri') when they violate the noble value they hold. So the quality of siri' will decrease if a person has an excessive or greedy desire, as in the case of a king who loses his power because of a disgraceful act (kasiri' siri'). The shame function can refer to as a social control tool.

Siri' can only work if it is associated with other custom elements. One important aspect that it includes religious quality, knowledge, good personality and wealth. So, siri' will have the impetus for his supporters to respect others and work hard with not contrary to religious values. Even siri' Considered a source of success of the people of South Sulawesi outside Their homeland. 
In youth organizations with religious background. Can be seen from the Perspective of religion, siri' directs how the Bugis-Makassar people serve God and provide normative rules that guide human behavior. People equated with animals if they do not obey the rules of religion. As is Depicted in the proverb which means 'if there is no siri', then There will be no religion, if there is no religion, then there will be no God, if there is no God, then there will be no heaven.

In different contexts, siri' functions as Attack and defense of Bugis and Makassar people against shame It receives. Even to maintain the shame, Bugis people prefers to die at war rather than live and bear 'Ripakasiri' (being humaliated). In this context, it is tangent to the value of maintaining wholeness and maintaining the name of the organization.

From the results of the study showed a number of individuals within the organization is very arrogant if the organization is pressed by a number of individuals even can-do violence. Things that should be positive can turn negative if self-esteem is trampled so that character education from siri' culture must be interpreted correctly not to have arrogance in the institutional that can lead to violence.

Then another culture that is absorbed in the youth organization that is pacce (pain) literally means a sense of pain and pain that pervasive pervasive in one's heart because of seeing the suffering of others. Pacce serves as a tool for unity, solidarity, togetherness, humanity, and motivation to try, even in a very complicated and dangerous situation. Can be interpreted that pacce is fostering a sense of unity and unity, fostering solidarity between people to want to help someone who has difficulty.

From the research result, it is found that understanding of pacce culture in youth organization in south sulawesi is understood that organization gives a lot of influence to the character and self-psychological. Because in general the organization is a collection of individuals that are heterogeneous so that they must learn to adapt in addition to the new atmosphere, as well as with various individual characteristics. It is this pluralism that encourages the growth of a sense of kinship that does not arise unknowingly and become a shared responsibility to maintain harmony and organizational integrity. Indeed, many positive things are given by an organization whose core is a valuable experience and learning for each individual to respond to what a person feels in an organizational unit, solidarity and a sense of brotherhood when it comes to joining a youth organization unit.

\section{The Process of Development Of Local Wisdom Becomes Character Education}

The observed organizational developments show a number of interesting points from interviews that the youth organization carries a different self-character but still remembers the origin of the culture adopted into the youth organization foundation. The socio-cultural foundation of the organization includes the social forces of society that are always evolving and changing in accordance with the times. Such strengths can be real and potential forces that are influential in educational and sociocultural development along with the dynamics of society.

Youth with all the spirit will be more focused when guided and nurtured properly. The role that will bring changes to society that can be realized in the organization. And in human life has the nature to accept or not accept something, including the attitude of youth in organizing. The education of the embedded character of the culture of siri' (ashamed) and pacce' (pain) has broad meaning rather than moral education, because it is not just teaching what is right and wrong, but more than that. Character education instills good habits, so that youth in the organization become cognitive (domain cognitive) about which ones are good and which are bad, and youth are able to feel and live (affective domains) of good value, and commonly do so (psychomotor domains).

The cultural foundation in educational activities is very important to do in the organization, because education is a process of cultural transformation from one generation to another generation. The social system of the youth institution as a container that has a structure of process activities and patterns of interaction that will determine the program and achievement of organizational goals. The organizational leader is the role holder who must know its function in the overall culture within the organization.

Youth organizations in addition to offering associations based on educational backgrounds and interests also provide education value. it is a process of making people accept culture, making people behave to follow the accepted culture. Enculturation takes place everywhere, in every place of one's life and at all times. Based on the above mentioned the sense of solidarity adopted from pacce culture. In outline wherever people are located then the place is also happening the process of education and enculturation. The youth organization is one of the places of enculturation.

The study finds a number of things that affect a number of youth characters who have local 
wisdom such as siri' and pacce' in decision making at a meeting of shy or siri' organizations will arise if the leader in a youth organization breaks the oath or violates the decision he has set. The same emphasis if the leader sees his members facing problems then the leader will bend over backwards to protect the members this is the realization of pacce culture.

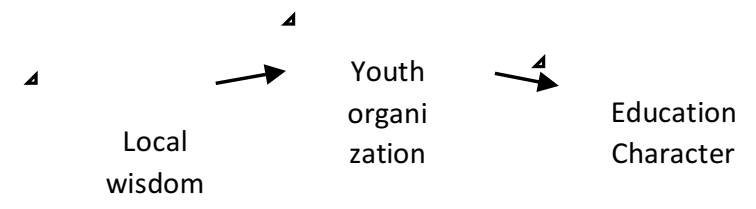

।

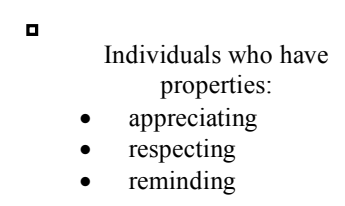

Source: Observation results and processed primary data, 2017

Culture that has grown in the organization is considered to be regulating and binding so it should be used as a life guide for all behavior and decision making because the value is considered ethical and noble so that this culture can still exist in the long term as long as not eliminate the whole cultural elements due to the conflict Occurs, while the process of development of local wisdom encourages the birth of character education can be seen in the above figure.

The occurrence of changes in cultural order is not only caused by external influences, but also due to internal influences due to the changing way of view of the organization. Culture is dynamic, growing and experiencing environmental influences. The change caused some elements of universal culture to reach the peak of arbitration in culmination and have a higher value.

Ultimately, this study describes the peak of individual actualization in several youth organizations such as Muhammadiyah Youth, Karang Taruna and KNPI South Sulawesi shows changes in the attitude of youth who have long wrestled within the scope of understanding of cultural organization that can be understood implicitly from the behavior of sipakatau (respecting), is the nature to look at human beings like humans. The point is that in our social life we should see people as fully human as any condition. In essence, we should respect each other human beings without seeing him poor or rich or under any circumstances.
Sipakainge' (reminding), is a reminiscent nature. Things that cannot be denied from humans that is, have shortcomings. Because of course man is not perfect, although man is his most perfect creation on earth. Sipakalebbi (appreciating), a trait that forbids us to see man with all his shortcomings. Like remembering the goodness of the people and forgetting the ugliness. Humans have a happy instinct in praise, so praise each other can clarify the atmosphere and tighten the bonds. These three attached attributes can last long if there is no conflict that hurt the mutual respect between the youth within the internal environment of their organization.

\section{CONCLUSION}

The cultivation of the character values of the youth can be carried out through the activities of youth organization, although it has various characteristics but the absorption of cultural values can function in it, one of the functions of shame culture in the siri' context can be seen as a tool of social control in organizing, In the organization is very arrogant if the organization is pressed by a number of individuals even cando violence. Things that should be positive can turn negative if self-esteem is trampled so that character education from siri' culture must be interpreted correctly not to have arrogance in the institution that can lead to violence. Furthermore, this pacce culture in youth organization in South Sulawesi understood that the organization gives a lot of influence to the character and psychological self. Because in general the organization is a collection of individuals who are heterogeneous so that they must learn to adapt to the new atmosphere so that gradually can bring solidarity because of the growth of family feeling. Moreover, the value of siri' (ashamed) and pacce (pain) cultures can evolve to form characteristics such as Sipakatau (Respecting), Sipakainge' (reminding), Sipakalebbi (appreciating) that can elicit characters with the characteristics of respect and respect for others.

\section{REFERENCES}

[1] Gobyah. The introduction of local wisdom of Indonesia (Pengenalan Keraifan Lokal Indonesia). Rineka Cipta: Jakarta. 2013.

[2] A.S. Keraf. Life Environment Ethic (Etika Lingkungan Hidup). Jakarta: Kompas. 2010.

[3] Alwasilah, A. Chaedar, dkk. Etnopedagogy Education Practical Foundation and Teacher Education (Etnopedagogi Landasan Praktek Pendidikan dan Pendidikan Guru). Bandung: Kiblat. 2009.

[4] Y. Apriyanto, Y. dkk. Local Wisdom in realizing sustainable water resouces management (Kearifan Lokal dalam Mewujudkan Pengelolaan Sumberdaya Air yang Berkelanjutan). Scientific paper from PKM IPB, Bogor. 2008. 
[5] Zulnuraini, Education Character. Concept, Its Implementation and Development in Elementary schools in Palu city) (Konsep, Implementasi Dan Pengembangannya di Sekolah Dasar di Kota Palu). Jurnal DIKDAS, No.1, Vol.1. 2012.

[6] Sriyatin. Cultivation and Development of Education Character Local Wisdom based in Elementary School Dersono iii Pacitan Universitas Muhammadiyah Surakarta. 2013.

[7] Nasir. Development of Character Education Local Culture based in SMPN 2 Kendari Universitas Muhammadiyah Surakarta. 2013.

[8] J.W. Creswell. Research Design Qualitative approach, Quantitative and Mixed. Yogyakarta: Pustaka Pelajar. 2010.

[9] Lexy J. Moleong. Qualitative research methodology. Revisid edition. Bandung: PT. Remaja Rosdakarya. 2012.

[10] Sugiyono. Quantitative research methodology, Qualitative and R\&D. Bandung: Afabeta. 2011. 